\title{
ERRATUM
}

\section{Erratum to: Simvastatin Rapidly and Reversibly Inhibits Insulin Secretion in Intact Single-Islet Cultures}

\author{
Valentina Scattolini - Camilla Luni · Alessandro Zambon · Silvia Galvanin • \\ Onelia Gagliano • Catalin Dacian Ciubotaru • Angelo Avogaro • \\ Fabio Mammano · Nicola Elvassore · Gian Paolo Fadini
}

Published online: November 30, 2016

(C) The Author(s) 2016. This article is published with open access at Springerlink.com

Erratum to: Diabetes Ther (2016) 7:679-693

DOI 10.1007/s13300-016-0210-y

In the original publication, a statement of equal contribution was not included. The text should read as: Valentina Scattolini and Camilla Luni contributed equally to the manuscript.

V. Scattolini and C. Luni contributed equally to the manuscript.

The online version of the original article can be found under doi:10.1007/s13300-016-0210-y.

V. Scattolini · A. Avogaro · G. P. Fadini $(\bowtie)$

Department of Medicine, University of Padova, Via Giustiniani 2, 35129 Padua, Italy e-mail: gianpaolo.fadini@unipd.it

V. Scattolini - C. Luni - A. Zambon - S. Galvanin · O. Gagliano · N. Elvassore $(\varangle)$ · G. P. Fadini Venetian Institute of Molecular Medicine,

Via Orus 2, 35128 Padua, Italy

e-mail: nicola.elvassore@unipd.it

C. Luni

Shanghai Institute for Advanced Immunochemical Studies, ShanghaiTech University, 99 Haike Road, Shanghai 201210, China
Open Access. This article is distributed under the terms of the Creative Commons Attribution-NonCommercial 4.0 International License (http://creativecommons.org/licenses/ by-nc/4.0/), which permits any noncommercial use, distribution, and reproduction in any medium, provided you give appropriate credit to the original author(s) and the source, provide a link to the Creative Commons license, and indicate if changes were made.

C. Luni · A. Zambon · S. Galvanin - O. Gagliano ·

N. Elvassore

Department of Industrial Engineering, University of

Padova, Via Marzolo 9, 35131 Padua, Italy

C. D. Ciubotaru · F. Mammano

CNR Institute of Cell Biology and Neurobiology, 00015 Monterotondo, Italy

F. Mammano

Department of Physics, University of Padova, Via Marzolo 8, 35131 Padua, Italy 